\title{
The Charter Revolution and the Court Party
}

F. L. Morton

Follow this and additional works at: http://digitalcommons.osgoode.yorku.ca/ohlj Special Issue Article

\section{Citation Information}

Morton, F. L.. "The Charter Revolution and the Court Party." Osgoode Hall Law Journal 30.3 (1992) : 627-652.

http://digitalcommons.osgoode.yorku.ca/ohlj/vol30/iss3/7

This Special Issue Article is brought to you for free and open access by the Journals at Osgoode Digital Commons. It has been accepted for inclusion in Osgoode Hall Law Journal by an authorized editor of Osgoode Digital Commons. 


\title{
THE CHARTER REVOLUTION AND THE COURT PARTY ${ }^{\circ}$
}

\author{
BY F.L. MORTON*
}

If you had told the people what the Charter was going to mean in 1982 -with respect to things like abortion and the Lord's Prayer-you never would have gotten it.

- The Honourable David Peterson, former Premier of Ontario 1

We have learned that the growth in judicial forms of power has been at the expense of and in direct opposition to other more popular forms of power. Herein lies its expediency. Law has been a way of getting around the people. ... Law [is] used to achieve an end too difficult to achieve by exclusive reliance on representative institutions or other democratic methods.

- Michael Mandel, Professor of Law, Osgoode Hall Law School ${ }^{2}$

Just as the 1960s are remembered by Canadian historians as the decade of the Quiet Revolution, so the 1980s will be remembered as the decade of the Charter Revolution. The adoption of the Charter of Rights and Freedoms ${ }^{3}$ in 1982 has transformed both the practice and theory of Canadian politics. It has replaced a century-old tradition of parliamentary supremacy with a new regime of constitutional supremacy that verges on judicial supremacy. Judges have abandoned the deference and

\section{Copyright, 1992, F.L. Morton.}

* Department of Political Science, University of Calgary. This is a revised version of a paper prepared for the Round-table Conference on the Impact of the Charter on the Public Policy Process, Centre for Public Law and Public Policy, York University, 15-16 November 1991 [hereinafter Round-table Conference]. Note that all quotations of oral remarks at the Conference remain subject to verification from a taped transcript of Conference proceedings. I wish to acknowledge the helpful criticisms made by Peter H. Russell, Rainer Knopff, and Michael Mandel of an earlier version of this paper. The research reported in this paper was supported in part by the Social Sciences and Humanities Research Council.

1 Oral remarks at the Round-table Conference, York University, November 1991 [unpublished].

${ }^{2}$ The Charter of Rights and the Legalization of Politics in Canada (Toronto: Wall \& Thompson, 1989) at 33.

3 Part I of the Constitution Act, 1982, being schedule B of the Canada Act 1982 (U.K.), 1982, c.11 [hereinafter Charter]. 
self-restraint that characterized their pre-Charter jurisprudence and become active players in the political process. Encouraged by the judiciary's about-face, interest groups-many funded by the very governments whose laws they are challenging-have increasingly turned to the courts to advance their policy objectives. The Charter has made the courtroom a new arena for the pursuit of politics. Charter litigation-or its threat—also casts its shadow over the more traditional arenas of electoral, legislative, and administrative politics.

Aspects of this revolution have been confirmed by almost every participant in this conference. David Peterson opened the conference by alluding to the "massive changes" affected by the Charter. ${ }^{4}$ Patrick Monahan noted that in 1982 the focus of debate was whether the Charter transferred too much power to the courts, while in the 1990s-with the call for a social charter-the debate is whether to transfer still more power. ${ }^{5}$ Peter Hogg, one of Canada's foremost constitutional experts, spoke of the "tidal wave of rights consciousness that is engulfing the country" and "has permeated the consciousness of the current Supreme Court justices."6 Jeffrey Simpson catalogued the dramatic changes that have transformed Canadian politics in the past decade, and suggested that they cannot be understood without reference to the Charter. ${ }^{7}$ Scarcely a week goes by that policy makers do not face a new Charter ruling that obstructs or constricts policy formulation or administration. The effects on Ottawa policy makers of court decisions like Singh v. Canada (Minister of Employment and Immigration), ${ }^{8}$ R. v. Schachter, ${ }^{9}$ and $R$. v. $A s k o v^{10}$ have been described by a Justice Department lawyer as

\footnotetext{
${ }^{4}$ Supra note 1.

5 P.J. Monahan \& M.H. Finklestein, "The Charter of Rights and Public Policy in Canada" (1992) also in this volume at 501.

${ }^{6}$ P.W. Hogg, Address (Oral remarks at the Round-table Conference, York University, November 1991) [unpublished].

7 J. Simpson, "Remarks on the Impact of the Charter" (Paper presented at the Round-table Conference, York University, November 1991) [unpublished]. See p. 499, note 1.

8 [1985] 1 S.C.R. 177 [hereinafter Singh].

${ }^{9}$ [1992] 2 S.C.R. 679 (S.C.C.) affg [1990] 2 F.C. 129 (C.A.), affg [1988] 3 F.C. 515 (T.D.) [hereinafter Schachter].

10 [1990] 2 S.C.R. 1199 [hereinafter Askov].
} 
"bombshells" and "a shock to the system."11 The result, according to a cabinet-level policy professional from Ontario, is that "Charter awareness" now "permeates the corporate consciousness of government policy makers." 12

The Charter revolution is unfolding so quickly that it is hard to gain perspective on it. What is most obvious may not be articulated. So much is so new that we still do not have the concepts to describe what is happening. As usual, understanding and vocabulary lag behind action. This paper attempts to describe an important dimension of the Charter revolution that has thus far escaped explicit recognition-the Court Party. Even though the Court Party thesis has ideological connotations, my attempt here is neither to praise nor condemn, but to help us better understand the Charter revolution. 13

We must begin by understanding that the Charter itself is not so much the cause of the revolution as the means through which it is carried out. The Declaration of Independence did not cause the American revolution, nor did the Declaration of the Rights of Man cause the French revolution. A revolution cannot be made without leaders and the support of interested classes. Judges are professionally obliged to declare that the Charter requires their decisions, but this kind of formal legalism is hardly persuasive outside the courtroom.

What has given the Charter its political bite is the same thing that made the 1960 Bill of Rights ${ }^{14}$ toothless-judicial interpretation. The adoption of the "broad and purposive," "living tree" approach to interpreting Charter rights, the corollary demotion of "framers' intent" and "original understanding" as guides to (and thus restrictions on) judicial interpretation, the de facto presumption of statutory invalidity

11 M. Dawson, Associate Deputy Minister, Public Law, Department of Justice, Canada, "Impact of the Charter on Public Policy and the Department of Justice" (Paper presented at the Round-table Conference, York University, November 1991) also in this volume at 595.

12 J. Jai, Executive Coordinator, Cabinet Committee on Justice, 'Cabinet Office, Ontario, Address (Oral remarks at the Round-table Conference, York University, November 1991) [unpublished].

13 A longer, more complex and more critical presentation of the Court Party thesis may be found in F.L. Morton \& R. Knopff, "The Supreme Court as the Vanguard of the Intelligentsia: The Charter Movement as Post-Materialist Politics" in J. Ajzenstat, ed., Two Hundred Years of Canadian Constitutionalism (Ottawa: Canadian Study of Parliament Group, forthcoming).

14 R.S.C. 1985, App. III. 
that flows from the section 1 Oakes test ${ }^{15}$-these are all the product of judicial free will and were in no way required by the Charter. There are persuasive alternatives to each of the interpretive choices that were put before the Supreme Court in early Charter decisions and rejected by the judges. The judges drive the Charter, not vice versa. ${ }^{16}$

Yet it would be just as absurd to say that Canadian judges are the cause of the revolution as it is to say that the Charter is the cause. Left to their own devices, judges are hardly inclined to be a hotbed of political ferment. Like the Charter, judges are as much a means as a cause of the rights revolution in Canada. While judges are in the vanguard of the revolution, they are being pushed as much as they lead. The real force behind the Charter revolution is the Court Party.

The Court Party consists of the new constitutional stakeholders who emerged from the Constitution Act, 1982. ${ }^{17}$ They are the new citizens interest groups that have sprung up around their sections of the Charter. Some were formed during the period of Charter-making and were active in shaping the Charter's content and then contributing the support necessary for its adoption. Others have sprung up in response to the Charter. Initially an ad hoc alliance, these groups forged more explicit ties and signalled their new-found power during their common opposition to the 1987 Meech Lake Accord. Deborah Coyne, Chairperson of the Canadian Coalition on the Constitution, has provided a (self) definition of the new Court Party:

The Charter's appeal to our non-territorial identities-shared characteristics such as gender, ethnicity and disability-is finding concrete expression in an emerging new power structure in society. ... This power structure involves new networks and coalitions among women, the disabled, aboriginal groups, social reform activists, church groups, environmentalists, ethno-cultural organizations, just to name a few. All these new groups have mobilized a broad range of interests that draw their inspiration from the Charter and the Constitution. ${ }^{18}$

The power of this coalition cannot be doubted, for it achieved what was unimaginable only a decade earlier-the defeat of a

15 R. v. Oakes, [1986] 1 S.C.R. 103.

16 This argument is developed more fully in R. Knopff \& F.L. Morton, Charter Politics (Toronto: Nelson Canada, 1992) c. 3.

17 Being Schedule B of the Canada Act 1982 (U.K.), 1982, c. 11.

18 "How to Escape the Meech Lake Morass and Other Misadventures" (Annual Meeting of the Council of Canadians, Ottawa, 14 October 1989) at 3 [unpublished]. 
constitutional amendment that enjoyed the support of all eleven first ministers and of the leaders of both opposition parties. While this coalition may have been initially an alliance of convenience and circumstance, it is now as entrenched in Canada's (small c) constitution as the Charter is in the (large C) Constitution.

Some might object that while these Charter Canadians are now active players in the arena of constitutional politics involving formal amendments to Canada's constitution, the label of Court Party does not fit. This objection fails to recognize the less obvious but equally significant process of informal constitutional amendment that goes on every day in the appeal courts of this country. While formal constitutional change is made purposely difficult to achieve, and, as a result, is rare, real change can and does occur in an incremental fashion through judicial interpretation. The reasoning of the judges adds new constitutional meaning that can expand or contract the rights-that is, the political influence- of the groups involved. Predictably, the various Charter groups have organized (some more effectively than others) to try to influence the judicial development of their respective sections of the Charter. ${ }^{19}$

Interest groups can achieve courtroom influence directly through the presentation of legal argument and extrinsic evidence when a group litigates or intervenes in a case. They can also exercise influence indirectly through Charter scholarship, influencing judicial appointments, or judicial education seminars after appointment. A wellorganized group pursues the judicial protection and expansion of its Charter turf on all four of these fronts simultaneously. This is the process that Alan Cairns so accurately captures in his concept of "Charter imperialism"-whereby the Charter's "various clientele seek to extend its jurisdiction." 20 What I call the Court Party is the agency of what Cairns describes as "Charter imperialism."

The feminist Legal Education and Action Fund ${ }^{21}$ provides the prototype of the "Charter imperialism" practiced by Court Party activists. After having heavily influenced the wording of the equality rights sections (15 and 28$)$ of the Charter, feminist leaders still realized that

\footnotetext{
${ }^{19}$ See supra note 16 at c. 2 and at c. 4.

20 A. Cairns, "The Charter: A Political Science Perspective," (Paper presented at the Roundtable Conference, York University, November 1991) also in this volume at 615.

21 Hereinafter LEAF.
} 
"rights on paper mean nothing unless the courts correctly interpret their scope and application."22 To try to insure that Canadian judges gave the "correct" interpretation to the Charter, feminists undertook an ambitious campaign of what they described as "influencing the influencers." 23 This campaign included "having national consultations, planning conferences, writing books ... making speeches, doing audits, [and] offering workshops." While the activities were varied, they shared the same purpose: "shaping the legal community's views, and the judiciary's in particular, on the meaning of equality."24 In 1984 the Canadian Advisory Council on the Status of Women published a study calling for the creation of a single, nationwide "legal action fund" to coordinate and pay for a policy of "systematic litigation" of strategic test cases. ${ }^{25}$ The study reported that, with the adoption of the Charter, "we find ourselves at the opportune moment to stress litigation as a vehicle for social change."26 A year later LEAF was launched, and it has gone on to become the most frequent and most successful non-government intervener in Charter cases before the Supreme Court. ${ }^{27}$

What is true of LEAF is true of a rapidly growing list of groups with a similar political genesis: the Canadian Disability Rights Council; the Charter Committee on Poverty Issues; the Canadian Prisoners' Rights Network; the Advocacy Group for the Environmentally Sensitive; the Equality Rights Committee of the Canadian Ethno-cultural Council; and Equality for Gays and Lesbians Everywhere, to name just a few. ${ }^{28}$

These Charter groups are distinct from traditional interest groups in several significant respects. First, they are organized around the

22 S. Razack, Canadian Feminism and the Law: The Women's Legal Education and Action Fund and the Pursuit of Equality (Toronto: Second Story Press, 1991) at 36.

23 Ibid. at 37.

${ }^{24}$ Ibid. at 36 and at 38 .

25 M.E. Atcheson, M. Eberts \& B. Symes, Women and Legal Action: Precedents, Resources and Strategies for the Future (Ottawa: Canadian Advisory Council on the Status of Women, 1984) at 16668.

26 Ibid.

27 See Tables 1.2, 3.1 and 3.2 in I. Brodie, Interest Groups and the Charter of Rights and Freedoms- Interveners at the Supreme Court of Canada (M.A. Thesis, University of Calgary, 1992) [unpublished].

28 Canadian Council on Social Development, Annual Reports of the Equality Rights Panel of the Court Challenges Program, 1987-88, 1988-89, and 1989-90 [unpublished]. 
promotion of ideas or causes rather than the occupational self-interest of their membership. ${ }^{29}$ Rather than trying to protect a narrow portion of the policy pie, most want to reform society as a whole. As Elizabeth Shilton, a LEAF representative told this Conference, "I am a feminist litigator, and I am in the business of social change." 30

The reformist bent of Court Party objectives means that the object of their litigation is often to increase the scope of state benefits, services or regulation rather than to limit the state, or alternatively, to defend interventionist redistributive policies already in the statute books. The extension of government services and benefits is the objective of most suits brought by section 23 minority language groups and frequently of cases brought by feminists and other equality seekers. As LEAF litigator Elizabeth Shilton stated,

While some rights may legitimately be seen as best protected by an absence of government regulation, the promotion of equality requires governments to take positive action to bring about social change. If disadvantaged groups are to achieve substantive equality in our society, they will require aggressive assistance from governmental action, by way both of positive law and social programmes. 31

LEAF has intervened in several cases to urge judges to adopt "remedies of extension"-judicial orders to government to extend benefit programs to the excluded gender category. 32 Such affirmative remedies infringe upon the government's historical responsibility for public expenditures and were unheard of in Canada prior to the Charter. In July 1992, LEAF and other advocates of greater state intervention to achieve equality of results celebrated when the Supreme Court ruled unanimously that judges can order governments to extend benefit programmes to previously excluded groups. ${ }^{33}$

29 The development of such "citizens' interest groups" predates the Charter, and has even stronger parallels in American politics. Since the 1960s, however, citizens' groups have been the fastest growing kind of interest group in both Canada and the U.S. See J.L. Walker, "The Origins and Maintenance of Interest Groups in America" (1983) 77:2 Am. Pol. Sci. Rev. 390.

30 E. Shilton, Address (Oral remarks at the Round-table Conference, York University, November 1991) [unpublished].

31 E. Shilton, "Charter Litigation and the Policy Processes of Government: A Public Interest Perspective" (Paper presented at the Round-table Conference, York University, November 1991) also in this volume at 653 .

32 See supra note 22 at $66,88,90$, and at 93 .

33 Schachter, supra note 9. 
The active presence of some conservative groups in the arena of Charter politics may appear to challenge the proposition that the Court Party is ideologically homogeneous. Real Equal Active for Life ${ }^{34}$-a conservative women's group committed to the defence of traditional family and moral values-has intervened in most of the same cases as LEAF but always on the opposite side. Other conservative groups active in Charter litigation include the National Citizens' Coalition, ${ }^{35}$ Joe Borowski's Alliance against Abortion, Men and Women for a Fair Market Wage, and Kids First. ${ }^{36}$

Upon closer examination, however, these groups' record of consistent failure actually confirms the ideological bias of Charter politics. On appeal, the NCC's trial victory in the Lavigne case was summarily rejected by the Ontario Court of Appeal. 37 The Supreme Court of Canada affirmed this rejection, and then took the unprecedented step of ordering Lavigne (and thus the NCC) to pay the court costs of the three groups that intervened to oppose Lavigne. ${ }^{38}$ Unless the Court applies this policy to future Charter cases-which seems extremely unlikely since it would clearly deter would-be Charter claimants-it is hard to avoid concluding that the Court was simply punishing the NCC and warning it and other pro-business groups not to return with any similar cases. REAL Women has been on the losing side of every Supreme Court Charter decision in which it has intervened. Borowski's Charter-based "right-to-life" argument was rejected by two

\footnotetext{
34 Hereinafter REAL Women.
}

35 National Citizens' Coalition Inc. v. Canada (A.G.) (1984), 5 W.W.R. 436 (Alta. Q.B.). This decision was handed down on the eve of the 1984 federal elections and, because of time constraints, was never appealed by the federal government. The National Citizens' Coalition [hereinafter NCC] successfully challenged restrictions on independent third-party (political action committec) expenditures in the Canada Elections Act, R.S.C. 1985, c. E-2, and sponsored Merve Lavigne's initially successful challenge to the union practice of using mandatory membership dues to support various political causes totally unrelated to collective bargaining. Re Lavigne and OPSEU (1986), 55 O.R. (2d) 449, 29 D.L.R. (4th) 321.

36 Kids First is challenging the provisions of the Income Tax Act, S.C. 1970-71-72, c. 63, that deny deductions for child care to stay-at-home parents. They claim this policy unfairly discriminates against couples who decide to raise young children themselves rather than use daycare. C. Howes, "Family Defies Child Tax Law" Calgary Herald (2 December 1989) B1; and R. Walker, "Child Tax Law Challenge in the Mail" Calgary Herald (30 April 1990) B1.

37 Lavigne and OPSEU (1989), 31 O.A.C. 40, 56 D.L.R. (4th) 474.

38 Lavigne v. OPSEU, [1991] 2 S.C.R. 211. S. Bindman, "Teacher saddled with court costs" [Vancouver] Sun (4 October 1991) A11. 
lower courts. ${ }^{39}$ The Supreme Court then pulled the plug on his last appeal by rendering the case moot when it struck down the abortion law in $R$. v. Morgentale ${ }^{40}$ several months prior to Borowski's appeal hearing. In sum, these conservative groups may be Court Party wannabes, but their dismal bottom line shows that they are decidedly swimming against the ideological tide. ${ }^{41}$

The ideological, reformist nature of most Charter groups may account for another distinctive characteristic-their state connectedness. Rather than relying on membership funding for their operating budget like vocation-based interest groups, most Court Party groups are funded primarily by the state. For some this results in clientele relationships with the state. Equality seekers can hardly mount "aggressive ... social programmes" without the active assistance of government. ${ }^{42}$ While the rhetoric of rights has an anti-statist ring, the reality is more often that a Charter group is working with one sector of the state (usually administrative or judicial) against another (usually the elected government).

The state/Court Party connection may also help explain what at first appears to be a paradoxical increase of interest group interventions in Charter litigation to defend government policy. A recent study of Supreme Court Charter decisions found that from 1988 to 1990 there were more private interest group interventions in the Supreme Court opposing individual Charter claimants (43) than supporting (23). LEAF is a leading example! 43 Assuming deeds speak louder than words, LEAF is thus no more pro-Charter than REAL Women. Both are pro-Charter so long as it is the correct (that is, their) version of the Charter, but quickly intervene to oppose Charter claims that would jeopardize their policy

39 Canada (Minister of Justice and Minister of Finance) v. Borowski [1981] 2 S.C.R. 575 [hereinafter Borowski].

40 [1988] 1 S.C.R. 30 [hereinafter Morgentaler].

41 Anyone who doubts the ideological orientation of the Charter subculture could compare the receptions accorded by Canadian law schools to the likes of Justice Bertha Wilson (the leading Charter activist on the Supreme Court), Henry Morgentaler, or Mary Eberts (leading counsel for LEAF) with the non-invitation of people like Justice William McIntyre (apostle of judicial selfrestraint), Joe Borowski, Gwen Landolt (counsel for REAL Women), or David Somerville (director of the NCC). The former are welcomed as conquering heroes, while the latter are treated like political lepers.

\footnotetext{
42 E.J. Shilton, supra note 31.

43 Brodie, supra note 27.
} 
objectives. Their goal is not to maximize Charter values, but to use (judicial interpretation of) the Charter to maximize their values. Sometimes this may entail an offensive strategy of using the Charter to challenge a statute, but it may just as easily mean defending government policy by opposing a rights claim made by others. From an interest group perspective, the Charter is a means not an end.

Just as the state is present in the Court Party, so the Court Party can be found within the administrative state. State involvement is essentially fourfold: public funding of Charter litigation; providing the institutional playing field and personnel in the form of courts and human rights commissions; engaging in a Charter clearance process within government prior to the introduction of new policy; and indirectly through the public funding of universities, providing the home base of constitutional experts and policy intellectuals.

The Department of Secretary of State programmes and the Court Challenges Program are the two most direct funding mechanisms for groups with official Charter status. The former provides core funding for many Charter groups while the latter distributes litigation grants-up to $\$ 105,000$ per case-to pay for their legal expenses. At the provincial level, the government of Ontario set aside one million dollars to pay for equality litigation. Less direct but still significant funding is channelled through education and research programmes administered by the Social Sciences and Humanities Research Council and the Human Rights Fund in the Justice Department. Much of this research funding goes to "Charter experts" in the universities. Since most Charter experts are also Charterphiles, to support their research is usually to support the new genre of advocacy scholarship intended to advance the policy agendas of the various Charter groups.44

Critics of the Court Party thesis have pointed out that the public funding described above constitutes a minuscule proportion of the total public funding of Charter litigation, the lion's share of which comes from provincial legal aid programmes. This funding is used to pay lawyers for the garden variety criminal cases that constitute seventy-five per cent of all Charter litigation. This criticism not only misses the point-that only certain interest groups are given public funding (that is, LEAF but not

44 See A.C. Cairns, Disruptions: Constitutional Struggles from the Charter to Meech Lake (Toronto: McClelland and Stewart, 1991) at c. 9. 
REAL Women)-but can actually be used to support the Court Party thesis.

With the advent of the Charter, the costs of legal aid-the tax dollars transferred from the pockets of private and corporate taxpayers to the legal profession-have skyrocketed. In Ontario, the budget for legal aid has gone up almost fourfold in 10 years, from $\$ 56.2$ million in 1982 to $\$ 213$ million in 1992.45 In Alberta, the legal aid budget rose by 42 per cent in 1992 alone. ${ }^{46}$ Many of the increases in the 1992 Ontario budget were attributed explicitly to Supreme Court Charter decisions such as Singh and Askov. ${ }^{47}$ It is certain that similar increases have been incurred in the budgets of both federal and provincial attorneys general to cope with the explosion of Charter litigation, criminal and civil. In sum, while the Charter (read: the Supreme Court) has been giving criminal defendants more rights, it has simultaneously been giving Canadian lawyers a cash cow worth tens-perhaps hundreds-of millions of dollars. This kind of financial incentive has created a strong clientele of Charter (read: Court) supporters not just among Court Party activists but lawyers in general.

Certain sectors of the state bureaucracy participate directly in Charter politics as adjudicators of disputes about rights. This is most obviously true of judges. Judges are the agency through which Charter potential becomes actualized. At the Supreme Court level, judicial interpretations become synonymous with the Charter. The "indeterminate wording" of Charter wording allows for different interpretations and results. In the United States it has long been recognized that the judge is often more important than the constitution in determining the outcome of a case. This explains the increasingly partisan and public conflict over American Supreme Court

45 Law Society of Upper Canada, Ontario Legal Aid Plan Annual Report (Toronto: Law Society of Upper Canada, 1982) at 5. Legal Aid Committee of the Law Society of Upper Canada, Press Release, "Legal Aid Assists Over 400,000 in 1990-91" (25 March 1992).

46 From $\$ 15.6$ million to $\$ 22.2$ million. M. Zurowski, "Legal Aid Funds Rise 42 Per Cent" Calgary Herald (18 April 1992) B2.

47 Singh, supra note 8; and Askov, supra note 10. The number of legal aid certificates issued for refugee determination hearings increased a staggering $950 \%$ just since 1989 . These hearings were required by amendments to the Immigration Act, R.S.C. 1985, c. I-2, made necessary by Supreme Court's 1985 ruling in Singh. Legal Aid Committee of the Law Society of Upper Canada, supra note 45. 
appointments, as witnessed by the Robert Bork and Clarence Thomas nominations. ${ }^{48}$

Experience in Canada under the Charter has confirmed that different judges produce different results. Studies found that Justice Bertha Wilson was twice as likely to rule in favour of Charter claimants as Justice William McIntyre.49 While the secretive and closed appointment process precludes any public challenges to the federal government's judicial appointments, this does not mean that behind the scenes groups are not trying to influence the appointment of sympathetic judges. At the 1991 Round-table Conference at York University, Marilou McPhedran, a leading feminist legal activist in Ontario, challenged several speakers who spoke as if there were no politics in the appointment process. "We're not being completely honest about the present appointment process," she declared. "We've all been involved in judicial appointments." 50 Perhaps she was referring to efforts by the National Action Committee in 1981, on the eve of the adoption of the Charter, to persuade the Trudeau government to appoint to the Supreme Court of Canada a woman justice "acceptable to our purposes." 51 Several months later Trudeau appointed Bertha Wilson to the Court, its first ever woman member, who went on to be an outspoken advocate of feminist values. A more open attempt to influence the judicial mind has been the successful effort by feminist groups to institute special education seminars for sitting judges on sexual equality and systemic discrimination. 52

Less obvious than the judges, but still important, is the influence of in-house government lawyers in the Charter clearance process described by other contributions to the Round-table Conference. This new Charter clearance process has become institutionalized in the policy

48 See F.L. Morton, "Judicial Appointments in the U.S. Supreme Court: The Judge Bork Affair" in F.L. Morton, ed., Law, Politics and the Judicial Process in Canada, 2d ed. (Calgary: University of Calgary Press, 1992) 106.

49 F.L. Morton, P.H. Russell \& M.J. Withey, "The Supreme Court's First One Hundred Charter of Rights Decisions: A Statistical Analysis" (1992) 30 Osgoode Hall L. J. 1.

50 Oral Remarks (Round-table Conference, York University, November 1991).

51 M.-A. Nixon, "Justice Committee Report," in National Action Committee on the Status of Women, Memo (Toronto: National Action Committee on the Status of Women, 5 September 1981) at 5 .

52 See Morton, supra note 48,69 at $82-83$. 
formulation process, conferring on the Attorney General's office a central agency status previously reserved for the Ministers of Finance and Treasury. Whether this amounts to a "Charter veto" 53 or simply "an additional level of scrutiny," 54 it has undeniably contributed to a "lawyerization of the policy process." 55 The indeterminacy of Charter meaning tends to confer considerable discretion, and thus considerable power, on Charter advisors. As the Honourable Ian Scott, the former Attorney General of Ontario observed, "Charter considerations and the threat of litigation can be used by government lawyers and policy makers to defeat policy objectives of which they do not approve or which they do not understand." 56 There is thus a hidden stage of Charter politics that kicks into operation long before legislation is introduced or challenged in the courts.

Recently the Supreme Court ruled that certain kinds of administrative tribunals also have jurisdiction to apply the Charter and to refuse to enforce offending statutes. ${ }^{57}$ This precedent extends the power of judicial review to additional thousands of adjudicators who sit on administrative boards and tribunals. This development has been generally supported by Charter scholars, despite its clear challenge to legislative primacy in the administrative process and its potential disruptive effect on policy. For the Court Party, however, this is generally seen as a positive development since it multiplies the points at which member groups with effective policy networks within the administrative branch can attempt to obstruct or change government policy. ${ }^{58}$

53 As suggested by Monahan, supra note 5.

54 As suggested by Jai, supra note 12.

55 L. Taman, former Assistant Deputy Attorney General for Constitutional Law and Policy for Ontario, Oral Remarks (Round-table Conference, York University, November 1991).

56 "The Charter and Public Policy" (Paper presented at the Round-table Conference, York University, November 1991) at 8 [unpublished]. See p. 499, note 1.

57 Cuddy Chicks Lid. v. Ontario Labour Relations Board, [1991] 2 S.C.R. 5.

58 See R. Devins, "A Perspective from the Ontario Human Rights Commission" (Paper presented at the Round-table Conference, York University, November 1991) at 5-7 [unpublished]. See p. 499, note 1. For another recent example of this, see E. Oziewicz, "Refugee Delays Ruled Unlawful; Immigration Adjudicator's Decision May Affect Huge Backlog" The [Toronto]Globe and Mail (10 October 1991) A1. 
Finally, there is the entirely different but related sphere of federal and provincial human rights acts and their superintending commissions and boards of inquiry. While the explicit target of these acts is "private discrimination," the commissions are administered by human rights enthusiasts drawn from the same groups and law schools as the major section 15 "equality seekers." Their dispute resolving mechanism - boards of inquiry-are invariably staffed with one or two "human rights experts" from the local faculty of law. The policy agenda shared by both groups is not so much to "protect society" from the state as to reform society through the state in the name of equality rights. 59 As one of their representatives has put it, "[w]e are essentially in the same business as the Charter."60

In November 1991, a representative of the Ontario Human Rights Commission recounted how the Commission undertook to use the Charter to expand the scope of its jurisdiction by challenging the exclusion of sexual orientation from the Human Rights Code ${ }^{61}$ as itself a violation of the equality guarantees of the Charter. ${ }^{62}$ Nine months later this creative attempt to transform what is nominally a state-limiting instrument (the Charter) into a state-expanding instrument (prohibitions on private discrimination) succeeded. The Ontario Court of Appeal ruled that the omission of sexual orientation from the list of prohibited forms of discrimination was itself a violation of section 15 of the Charter. ${ }^{63}$

59 See R. Knopff, Human Rights and Social Technology: The New War on Discrimination (Ottawa: Carleton University Press, 1989) at 17-33.

60 R. Devins, Oral Remarks (Round-table Conference, York University, November 1991). Devins makes the same point on the first page of her paper: "Thus, we [the Commission] are part of an extended family of equity forums that engage us with the Charter at a fundamental level." Supra note 58.

\footnotetext{
61 R.S.O. 1990, c. H.19.

62 Devins, supra note 58.
}

63 Leshner v. Ontario (A.G.) (1992), 10 O.R. (3d) 732 (Ont. C.A.) [hereinafter Lesiner]. The Leshner case is a good example of the "insider" quality of the Court Party, since it represents an individual enlisting the support of rights enthusiasts in one part of the bureaucracy, the Human Rights Commission, to lobby rights enthusiasts successfully in another branch of the bureaucracy, the courts. Indeed, Mr. Leshner himself was a lawyer employed in the office of the Altorney General of Ontario. Several days later, The Globe and Mail gave its editorial blessing to the decision, rejoicing in how "homosexual rights advocates have recorded victory after victory in the courts," and lamenting how "governments, sadly, have been many steps behind the judiciary." "The rights of homosexual couples" The [Toronto] Globe and Mail (3 September 1992) A14. 
The universities-especially the law schools-are perhaps the most important constituency of the Court Party. They provide both the personnel and the ideas that drive the Charter movement. Law schools now produce a steady stream of rights experts to staff the interest groups, funding agencies, human rights commissions, boards of inquiry, and courts that pursue the politics of rights. Of special significance are the scores of engagé law professors who serve on the boards and litigation committees of Charter-oriented interest groups. The research interests and legal expertise of these professors usually dovetail with the cases they work on. Their research thus supports their politics, and their politics in turn feeds their research. The distinction between education and political action is dissolved completely by the mounting of Charter litigation projects within some law schools.

Charter scholarship is the other great asset that the universities provide to the Court Party. While legal commentary has always been an importance influence on the development of jurisprudence, it has taken on added significance in the case of the Charter. The Charter represented a break with past Canadian jurisprudence-a sort of legal tabula rasa. As one federal lawyer told this conference, "[i]magine the difficulty of advising the government what the Charter means when there have been no decisions." 64 This legal vacuum was quickly filled by an avalanche of new Charter scholarship. The Supreme Court has liberally availed itself of this new literature, explicitly citing it in support of its own Charter decisions.

The link to the Court Party is that there are very few Charter experts who are not also Charterphiles, at least in terms of their group's Charter sections. In the new constitutional politics of gender, race, ethnicity, and language, each of the official constitutional groups draws extensively on academic sympathizers for legal and political advice. The "extensive intermingling of the academic and political spheres," Cairns has observed, has produced a Charter "scholarship" that is increasingly "purpose driven and laced with advocacy." 65 A related trend has been "insiderism"- the belief that only a "member" of an ethnic, linguistic or

64 Dawson, supra note 11.

65 A. Cairns, supra note 44 at $214-21$ and at 218 . As if to prove Cairns's point, in October 1991, a conference entitled "Conversations Among Friends: Women and Constitutional Reform" was held at the University of Alberta Law School that listed nineteen panelists, all women (half of them lawyers). 
gender "group" can speak with any authority about its constitutional interests. ${ }^{66}$ Insiderism has contributed to the radicalization of legal scholarship because it discourages the traditional academic dialectic of criticism and reply. Outsider criticism of overstated or under-supported claims tends to be dismissed as misapprehension or simply hostility.

In this environment, treatment of Charter issues tends to be onesided. Counter-arguments and contrary precedents are often portrayed negatively or ignored altogether. For example, the most influential book-length commentary on section 15 does not contain a single article challenging or opposing the concepts of systemic discrimination or disparate impact. ${ }^{67}$ A reviewer concluded that this collection of essays gave the strong impression of "legal scholarship in the service of a social movement." 68 As it turned out, this was indeed the case. The book was an integral part of the feminist campaign of "influencing the influencers," carefully timed to appear the same year (1985) the section 15 equality rights were to take effect.69 Examples of one-sided scholarship could be endlessly multiplied. ${ }^{70}$

The advocacy, reformist character of Charter scholarship is neither surprising nor accidental. The same phenomenon has been at work in the United States for over thirty years: "since 1937, changes in public policy first have been mentioned in the nation's law reviews." "Flooding the law reviews" with favourable articles has been an established tactic of movement interest groups since it was first used by the National Asociation for the Advancement of Colored People in the

\footnotetext{
${ }^{66}$ Ibid. at 215-16.
}

67 A.F. Bayefsky \& M. Eberts, eds., Equality Rights and the Canadian Charter of Rights and Freedoms (Toronto: Carswell, 1985). For a critique of the systemic discrimination concept, see R. Knopff, "What do Constitutional Equality Rights Protect Canadians Against?" (1987) 20 Can. J. Pol. Sci. 265; and Knopff, supra note 59, especially c. 6.

${ }^{68}$ T.E. Flanagan, Book Review of Equality Rights and the Canadian Charter of Rights and Freedoms, ed. by A.F. Bayefsky \& M. Eberts (1986) 1 Can. J. Law \& Soc'y 174.

${ }^{69}$ Razack, supra note 22 at 36 and at 38.

70 It is all but impossible to find a law review article that argues for judicial self-restraint or narrow interpretation of Charter provisions. About the only exceptions are feminists, who support censorship of obscenity and oppose the rights of rapists; and Quebec nationalists, who argue in favour of narrow interpretations of the language rights of the Anglophone minority. Articles on the scope of the Charter's application overwhelmingly support the kind of broad definition of government action embraced by Justice Wilson in the mandatory retirement decisions. Articles on the issue of intervener participation in Charter cases unanimously endorse the open door policy that the Court ultimately adopted. 
fifties. The simultaneous appearance of numerous articles all supporting the same position puts judges and legal scholars on notice that there is support for the position advanced. ${ }^{71}$ This tactic promised to be especially effective with the Charter because, given the initial absence of any precedents, judges were likely to look to the law reviews for cues.

Just as the nineteenth century corporate bar in America "helped to translate the philosophy of laissez-faire [economics] into legal terms,"72 so the "public interest" lawyers in Canada today have translated the policy agenda of the Court Party into constitutional doctrines. This cascade of Charter scholarship has been an important contributing factor to the Supreme Court's shift from its pre-Charter self-restraint to its post-Charter activism. What Mary Ann Glendon has written of the American Court during the 1960s applies equally to Canada today: "[c]ourt majorities with an expansive view of the judicial role, and their academic admirers, propelled each other, like railwaymen on a handcar, along the line that led to the land of rights."73

There is thus a broad overlap between the state and the Court Party. Most Charter groups are heavily subsidized by the state, while many Court Party partisans find employment within the state. Indeed, a common career path for a Court Party activist would include multiple migrations between government employment, university appointments, and administrative or executive positions within his or her Charter-based group. University-based activists often hold all three simultaneously. Significantly, this entire career path is within the public sector.

Indeed, unlike the social benefit programmes favoured by earlier egalitarian reformers, the equality programmes favoured by the Court Party-such as employment equity, human rights commissions, and Charter litigation-result in little direct redistribution of wealth. Rather, most of the budgets for today's equality programmes are absorbed by the salaries of the rights experts who staff them, a disproportionate number

$71 \mathrm{~K}$. O'Connor, Women's Organizations' Use of the Courts (Toronto: D.C. Heath and Co., 1980) at 26.

72 L. Fisher, Constitutional Dialogues: Interpretation as a Political Process (Princeton, N.J.: Princeton University Press, 1988) at 17.

73 Rights Talk: The Impoverishment of Political Discourse (New York: The Free Press, 1991) at 7. Glendon also noted, at 6 , the multifaceted character of the university/court relationship: "[a]t the elbow, so to speak, of wise Supreme Court justices, would be renowned social scientists, lawyers armed with theories generated in the best law schools, and teams of young law clerks, fresh from the classroom and bearing the very latest word on constitutional law." 
of whom are lawyers. In other words, one of the primary economic beneficiaries of rights policies are rights experts.

Finally, there is a less tangible but important media component of the Court Party. Unlike the bureaucracies and the universities, the media have no direct link with Charter groups. Yet without sympathetic media coverage, the Court Party could not prosper. ${ }^{74}$ Today television provides the playing field for all politics, including Charter politics. Most importantly for the Court Party, it provides a medium to bypass governments and political parties and to go directly to the people-or more accurately, to public opinion. Winning Charter cases and persuading the courts to strike down a statute is not an end in itself. The real objective is insuring that the invalidated law or policy is not reenacted. This requires marshalling public opinion for or against the law or policy in question. The judicial decision becomes a means to this more important end. ${ }^{75}$ Charter victories become political resources to shape public opinion, but to succeed they need a public forum. The media provides this forum.

The media-especially television-have both a technical and a sociological affinity for the Charter. As Glendon has observed, the "strident language of rights" is "tailor-made" for the ten-second soundbites preferred by television news producers. ${ }^{76}$ Most Charter cases have the ingredients of good entertainment that prime-time producers are

74 While it is admittedly difficult to document such a proposition conclusively, I found that in the one extended Charter case study that I have done-Morgentaler and Borowski-there was consistent media support both in the press and behind the scenes for Dr. Morgentaler and the prochoice perspective. See the various entries under "media" and "Globe and Mail" in the index of F.L. Morton, Morgentaler v. Borowski: Abortion, the Charter and the Courts (Toronto: McClelland and Stewart, 1992).

75 The best example of this was the defeat of the government's attempt to re-enact a revised abortion law. The legal basis for the 1988 Morgentaler decision, supra note 40, was narrow and procedural-the lack of access and the delays caused by the required approval of a therapeutic abortion committee. The revised abortion bill abolished this requirement, thereby complying with the majority's reasoning. These subtleties were lost, however, in the public relations battle that ensued. Pro-choice advocates claimed that the Court had declared that the abortion law violated the Charter, and that now, the government was trying to re-enact an abortion law. The intended implication that the government was ignoring the Charter proved to be a powerful rhetorical card.

${ }^{76}$ Glendon, supra note 73 at $\mathrm{x}$-xi. 
looking for: "drama ... winners and losers, and an emotional element ... but most of all ... conflict."77

Even more than other news events, the media enjoy great freedom-and thus influence-in the negative or positive spin that they can put on Charter decisions. The overwhelming majority of Canadians never have the time to read Charter decisions for themselves, and even if they did, they could not understand the turgid legal prose in which they are written. Public understanding depends on-and thus is shaped by-translation of Supreme Court decisions by the national media into ordinary English and French. There are thus two stages of interpretation in Charter politics: the judges' interpretation of Charter text and then the media's interpretation of judicial text. ${ }^{78}$ No one disputes the power the first stage confers on judges. The second confers almost as much power on the media as they inform the "uncomprehending public"79 of the Court's most recent edicts.

The media, however, tend to suffer the same disabilities as most Canadians when it comes to Charter decisions: length of judgments, lack of time, and technical language. They circumvent these difficulties through interviews with Charter experts-frequently university law professors associated with the Charter groups involved in the case-who are expected to cut through the legalese of the judges and give the public a plain-language version of the decision. The media thus provide the interpretation of the interpretation. As often as not, these expert opinions reflect and thereby advance the political sympathies of their authors. $^{80}$ A reporter could of course seek out other experts with

77 D. Taras, "Television and Public Policy: The CBC's Coverage of the Meech Lake Accord" (1989) 15:3 Can. Pub. Pol'y 322 at 326.

78 I discuss this phenomenon of double interpretation or interpreting the interpreters at greater length in Morton, supra note 74 at 229-30.

79 This term is taken from Razack's description of the Toronto Star's front page headline-"High Court Launches New Legal Era With Equality Ruling" (2 February 1989) -communicating the ruling in Andrews v. Law Society of British Columbia, [1989] 1 S.C.R. 143, to "an uncomprehending public." Supra note 22 at 105 . While these headlines provide a particularly compelling example of positive media spin, the concept of an "uncomprehending public" is applicable to all Charter decisions.

80 There was some evidence of this in the days following Morgentaler. The media relied heavily on interviews with women lawyers and law professors, most of whom are also feminists. Consciously or not, there was a decided tendency to overstate the scope of the Court's decision: by quoting Madame Justice Wilson at length; by minimizing the narrow, procedural basis of the other four majority judges; and by ignoring the two dissenting judges altogether. There were also 
different views, but most do not. Time is short, producers impatient, and simplicity a virtue.

The media's uncritical use of Charter experts often reflects their more general sympathy for the goals espoused by Charter groups. Most reporters and news producers come from or are socialized into the same socio-economic milieu as the Court Party activists they cover. They are drawn almost exclusively from the service sector of the economy, and enjoy high levels of education, affluence, and mobility. They are all part of the most distinguishing feature of post-industrial society, the knowledge industry. In sum, the fifth estate is drawn from the same socio-economic strata as the Court Party, and it would be surprising if they did not share many of the same political orientations. ${ }^{81}$

The mutual penetration of the Court Party, the (various arms of the) state, and the media challenges the political disadvantage theory of interest group litigation, and provides an insight into why so many Charter groups are attracted to litigation as a preferred means of political action. According to the political disadvantage theoryadopted from earlier American experience-minorities who are marginalized or mistreated in the electoral/legislative process can turn to the courts for protection. The political disadvantage theory has now been abandoned in American political science, partly because of the increased use of litigation by pro-business groups, but also because of its own theoretical deficiencies-that is, why did disadvantaged minorities not use litigation before the 1950s and 1960s? ${ }^{82}$ Obviously, no disadvantaged minority can enjoy much success with constitutional litigation unless they have supporters in the legal and judicial élites that shape the practical meaning of a nation's constitutional law from one generation to the next. In other words, while litigation may still be

instances of extending the meaning of Morgentaler to include public funding of abortions, an issue that clearly was not addressed by the Supreme Court's decision.

81 Seymour Martin Lipset has observed that in post-war western democracies, the most dynamic agent of social change has not been Marx's industrial proletariat but a new "oppositionist intelligentsia," drawn from and supported by the well educated, more affluent strata of socicty. "The reform elements concerned with post-materialist or social issues largely derive their strength not from the workers and the less privileged, the social base of the Left in industrial society, but from segments of the well educated and affluent, students, academics, journalists, professionals and civil servants." S.M. Lipset, Consensus and Conflict: Essays in Political Sociology (New Brunswick: Transaction Books, 1985) at 196.

82 S.M. Olson, "Interest Group Litigation in Federal District Court: Beyond the Political Disadvantage Theory" (1990) 52:3 J. Pol. 854. 
thought of as an outside strategy (as opposed to traditional, inside strategies of electoral or legislative politics), it is likely to work only for insiders; that is, groups who are part of, or at least have allies in national legal/political elites..$^{83}$

This revised theory of constitutional litigation as an outside strategy for insiders fits the Canadian experience of the Court Party quite easily. The influence of feminists and other Charter groups on the drafting of the 1982 constitution and their successful campaign against the 1987 Meech Lake Accord suggest influence not powerlessness. The substantial state funding for Charter groups, their representation in the courts, law faculties, law journals, regulatory agencies, and the media-none of these are characteristics of politically disadvantaged minorities. ${ }^{84}$ The strategic advantages of litigation, not political disadvantage, provide a more persuasive explanation of Charter groups' attraction to the courts.

This also explains why this coalition of Charter-based groups can properly be labelled the Court Party. It is not because the Supreme Court is in charge of this movement. While the Court is the means through which the Court Party hopes to reform society, and the ultimate object of the Court Party's campaign to influence the influencers, to date, this campaign has met with mixed success. For every Wilson there has been a McIntyre, for every Lamer a LaForest. If the Court Party ever has its way, the Court will become the vanguard of the postmaterialist revolution, but that day has not yet come.

The Court Party label is appropriate because its partisans support the "judicialization of politics." Even before the Charter had been adopted, Peter Russell observed that its principal effect would not be the creation of new rights but a new way of making decisions about rights in which judges play a much more influential role. ${ }^{85}$ The rhetoric of rights notwithstanding, Charter proponents have always been aware of its transfer of institutional power to the courts. Indeed, as noted earlier, leading Charter groups such as LEAF come to the courts to oppose rights claims almost as often as they do to support them. In this respect, it is

83 This is the argument developed by Brodie, supra note 27 at c. 2 .

84 Ibid.

85 P.H. Russell, "The Effect of the Charter of Rights on the Policy-Making Role of Canadian Courts" (1982) 25 Can. Pub. Admin. 1. 
just as accurate and perhaps more realistic to describe them as the Court Party than as Charter Canadians.

Indeed, if one views the adoption of the Charter as a policy output and asks why it was chosen over other policy instruments, the answer is that its supporters thought that it was more likely to achieve certain desired policy results. This was incontestably the case with the minority language rights sections of the Charter, whose primary and intended effect was simply to transfer final authority for bilingual services and education out of the hands of unfriendly provincial legislatures to the more sympathetic environs of the federally appointed (and increasingly bilingual) superior courts. ${ }^{86}$ In other words, the choice of the Charter as a means of conducting government had an ideological or normative aspect. ${ }^{87}$ It was intended to advance certain interests by lifting them out of the electoral/legislative process and removing them to the courts.

Subsequent development of the Charter suggests that the Court Party's aversion to electoral and legislative politics is not limited to minority language issues. Most Charter cases deal not with clear-cut questions of rights but public policy issues "garbed in the cloth of rights." 88 Few if any Charter cases have dealt with an alleged violation of the core meaning of a civil liberty or legal right-a violation which all reasonable Canadians would condemn. Much more typical is the attempt to persuade a judge to stretch the existing meaning of a right to include a policy issue on which reasonable Canadians may very well differ. ${ }^{89}$ The attempt to pull such policy issues within the orbit of the Charter is premised on the belief that federally appointed judges will provide a more sympathetic hearing than elected legislatures.

This preference for the courts is implicit in the reformist policy agenda of many Charter groups. The new reformers must cope with what John Kenneth Galbraith has described as "something new in the

\footnotetext{
${ }^{86}$ Compare Mandel, supra note 2 at 29: "The reason Trudeau wanted the Charter in the first place was to use it against the unilingual tendencies of provincial governments in areas beyond federal control."

87 C. Jaekle, "The 'New' Judicial Ascendancy: Are Legislatures Abdicating Their Responsibilities?" at 32 [unpublished].

${ }^{88}$ Simpson, supra note 7 at 9.

89 For a fuller analysis of the "core meaning" versus "peripheral meaning" of Charter rights, see Knopff \& Morton, supra note 16 c. 6.
} 
history of democratic government ... the emergence of a comfortable middle class in a solid voting majority ... who aren't as interested in social reform as they are opposed to paying taxes to finance it." 90 Whereas previous reformers sought the electoral support of the masses to challenge the power and privilege of the few, for Court Party reformers, the masses are the problem that needs to be reformed. They suffer from a post-Marxist version of "false consciousness." 91 Unaware of their own racism, sexism, "specieism", and other prejudices, the middle classes are reluctant to embrace those who would "cure" them. ${ }^{92}$ This makes electoral success unlikely. The Charter allows postmaterialist reformers to recast their causes as cases and to take them to an alternative policy forum - the courts-beyond the immediate reach of public opinion.

In this respect, the Charter has not resulted in a democratization of Canadian politics. It has shifted responsibility for a growing sphere of policy issues into a new arena where the costs of participation are prohibitive and debate is conducted in a foreign language-Charterese, a dialect of legalese. The Court Party can be described as a democratic force with respect to its commitment to a policy of equality of results. Politically, however, it represents a horizontal transfer of power to a new élite, not a vertical transfer of power to the people. Gordon Stewart's description of the first Court Party in Canadian politics, the preConfederation reformers in Upper and Lower Canada, is still apt for the new Court Party: "They did not wish to reduce executive power; they wished to take it over and exercise it." 93

The anti-democratic character of the Court Party may not be a fatal flaw. It is consistent with the major trend in all western democracies-the decline of elected institutions and the ascendancy of the administrative state. It is also consistent with the character of Canadian democracy, which has never been of the grass roots variety. Deference to authority and élite accommodation have been its

\footnotetext{
90 As quoted by M. Bygrave, "Mind Your Language" Guardian Weekly (26 May 1991) 22.

91 Ibid.

92 See Knopff \& Morton, supra note 16 at c. 9.

93 The Origins of Canadian Politics: A Comparative Approach (Vancouver: University of
} British Columbia Press, 1986) at 30. 
trademarks. Perhaps the Court Party simply adds one more layer to Canada's governing élite.

In conclusion, most of the contributors to the Round-table Conference premised their observations on the assumption that it is the Charter that shapes policy and politics. This is the legal logic of constitutional law as the supreme law. As constitutional law the Charter trumps contrary laws. This approach is reflected in the title of the Conference: "The Impact of the Charter on the Public Policy Process"-and is certainly true at a prima facie level.

But at a deeper level, the view of the Charter as law as usual represents a legalistic and naïve understanding of constitutional law. While in theory constitutional law constrains politics, in practice, politics shapes constitutional development. As Edward Corwin, the celebrated American constitutional scholar, once observed, "[c]onstitutional law always has a central interest to guard." 94 This is undeniably clear in the changing currents of American constitutional development. Freedom of contract and states' rights, the pillars of American constitutional law for over a century, were abandoned overnight by the Supreme Court in 1937, never to return. ${ }^{95}$ The equal protection clause of the Fourteenth Amendment, ${ }^{96}$ which in 1927 Justice Holmes disparagingly referred to as "the last resort of constitutional arguments," 97 became after 1954 the most heavily litigated section of the constitution. In both examples, the text of the constitution remained the same, but its practical effect changed dramatically.

The shaping influence of politics on constitutional law is evident (if less dominant) in Canada's own experience. The federal powers of disallowance and reservation remain legally intact, yet it is now

94 E.S. Corwin, The Constitution and What It Means Today (Princeton, N.J.: Princeton University Press, 1946) at viii.

95 The Marshall Court (1801-1835) was a strong proponent of strengthening the new national government. Its successor, the Taney Court (1836-1864), was no less committed to the protection of the economic interests of the South and the West. The post-Civil War Court became the leading defender of pure laissez-faire economics and property rights against government regulation until its demise in 1937, while the post-New Deal Court was a silent partner in the building of the new welfare state. After 1954, the Warren Court became the governmental champion of the reform agenda of the new "urban majority," leading the way for the Black civil rights revolution and other liberal causes.

96 U.S. Const. amend. XIV, § 1.

97 Buck v. Bell, 274 U.S. 200, 208 (1927). 
universally accepted that they cannot be used to interfere with provincial policy initiatives. The same provincial rights movement that began the process of neutralizing disallowance and reservation also contributed to the Judicial Committee of the Privy Council's decentralizing interpretation of sections 91 and 92 of the Constitution Act, 1867.98 More recently, commentators such as Patrick Monahan have suggested that a similar fate has befallen the section 33 legislative override. While governments still have the legal right to exercise it, they will not for fear of political backlash. ${ }^{99}$

The point of both the American and Canadian examples is that constitutional rights and powers by themselves have no practical effect. They are only as strong or as weak as the élite (and ultimately public) opinion that is behind them. If no one believes in the principles enshrined in a right, it is unlikely to be given much judicial protection or, if it does, to find ready governmental compliance.

The weakness of the Charter as text is witnessed by the very industry of the Court Party. Their multi-pronged campaign of influencing the influencers-through litigation, scholarship, lobbying, judicial education, and appointments-is an attempt to ensure that there will be a climate of élite opinion that is receptive to the kinds of expansive interpretations that they want to see read in to the opentextured wording of their preferred Charter sections. If the Charter spoke for itself, none of these activities would be necessary.

A similar analysis must apply to the ascendancy of the courts qua institution under the Charter. The rise and fall of political institutions does not occur in a vacuum. Political power gravitates into the hands of those "most representative of dynamic new social forces." 100 In a system of government where representative functions are divided among different political institutions, "power has tended to shift from one body to another according to each body's success or

98 (U.K.), 30 \& 31 Vict., c. 3. See R.C. Vipond, Liberty and Community: Canadian Federalism and the Failure of the Constitution (Albany: State University of New York Press, 1991).

99 Supra note 5. The government of Quebec is the obvious exception to this prognosis. It should be noted that as recently as 1990, Alberta's Deputy Minister and Minister of Intergovernmental Affairs, Jim Horsman, defended Quebec's right to use section 33, and said that Alberta would be willing to do the same in similar circumstances. Address (Students' Union Meeting, University of Calgary, 5 February 1990) [unpublished].

100 W. Elliot, The Rise of Guardian Democracy: The Supreme Court's Role in Voting Rights Disputes, 1845-1869 (Cambridge, Mass.: Harvard University Press, 1974) at 7. 
failure in responding to powerful demands" from dominant or ascendant élites. ${ }^{101}$

The ascendency of the courts under the Charter is a political phenomenon that requires and deserves a political explanation. What are the social groups and interests that account for the emergence of the Charter and the politics of rights in Canada? What is the central interest that drives the Court's new activism and shapes its Charter jurisprudence? Until we begin to answer these questions we cannot adequately understand the Charter revolution and how it is affecting the policy-making process in Canada. Recognizing the presence and the purpose of the Court Party is a necessary first step.

101 Ibid. The triumph of Parliament over the monarchy in the seventeenth century and the eclipse of the House of Lords by the House of Commons in the nineteenth century signalled the rising influence of first, the landed aristocracy and subsequently, the urban bourgeoisie. 